position, running parallel to the right side of the larynx and trachea. The great vessels had escaped injury and she recovered after some weeks. She was watched by her relatives for some time, but giving no trouble surveillance ceased. Exactly one year after her first attempt, again on a Saturday, she successfully committed suicide by drowning in a shallow well, being found head downwards with the lid resting on her ankles.

It is astonishing what a healthy lot proposers for life insurance almost invariably say they are. Deliberate suppression of the truth or falsification is probably the exception, but unconscious bias in his own favour is, after all, only natural in the account given of his past health by an examinee. I always inquire of a proposer if he belongs to any benefit society or sick fund, and follow this up by asking how long he has been a member; then a tender inquiry if he has ever been on the funds and, if so, how often and for how long a time, and what for, usually brings to recollection some forgotten illness or indisposition. Quite frequently an individual will deny ever having suffered from rheumatism. but admits that he has had "growing pains." In these days of conscientious objectors and cranks it is as well to take note of vaccination. Insurance companies will probably find it necessary to revise their premiums in the case of the non-vaccinated, for that class is increasing all over the kingdom.

Recent legislation may bring the general practitioner more often into the law courts. The Workmen's Compensation Act offers chances which the malingerer does not neglect. We all know how fatal to fortitude is the fact that a sufferer belongs to two clubs, without the added inducement of compensation for accidental injury. That stock malady, the sprained back, an injury so easily obtained, so successfully simulated, so difficult to disprove with its entirely subjective symptoms and absence of all objective sign, and so prone to recurrence, with the "railway spines" and "nervous shocks," will be supplemented by other maladies. Ordinary illness, such as a common cold, will be said to be an accident, the result of following one's employment in bad weather, \&c.

\section{OPERATIVE TREATMENT IN CERTAIN CASES OF INSANITY.}

To the Editors of THE LANCET.

SIRs,-In cases of simple insanity-cases which cannot be referred to any structural lesion of the brain-there can be little doubt that disturbance of the cerebral circulation is an important, if not the essential, pathological factor. Anæmia of the brain and symptoms of mental depression necessarily follow a diminished supply of blood to the organ, and, on the other hand, if it is abnormally increased, hyperæmia and mental excitement will be the consequent effects. In cases in which the quality as well as the quantity of the bloodsupply is altered and in which an impediment to the return of blood from the head exists, the effect will not be so simple but will exhibit corresponding complications. Many cases of simple insanity, however, appear to depend almost entirely upon active hyperæmia and increased blood pressure. I allude to cases in which the individual's powers of perception, recollection, thought, emotion, and volition are all more or less intensified as well as perverted. The condition of these patients resembles very closely the delirious state of those suffering from pyrexia which is undoubtedly due to increased blood pressure. To the same cause also may be ascribed the mental excitement produced by stimulants and by the administration of ether or chloroform.

Delirium so closely resembles the acute form of mania that persons suffering from it have been improperly ordered into confinement as maniacs. The diagnostic difficulty is easily explained when we remember that increased blood pressure is the main cause in both cases. Again, in cases of mania the more acute the symptoms the greater the cerebral disturbance and insomnia, the more favourable is the prognosis. In such cases as soon as the flow of blood in the cerebral vessels returns to its normal state the mental derangement disappears, leaving the mind clear, as in delirium due to some febrile disease. There are cases, however, of acute mania which improve up to a certain point and then go no further but remain stationary for an indefinite time and at length exhibit signs of approaching dementia. Now the question arises, How is it that these cases do not recover? Is it because the arteries of the brain have become permanently enlarged and the supply of blood in such cases continues to be abnormally excessive? Oan nothing be done to lessen the supply? Why not ligature the carotid artery with this object in view? I have a case under my care of this kind at the present time and should like to hear the opinion of some of your readers on the above suggestion. Would the operation be likely to be of any value? Would it be justifiable to perform it ex. perimentally with the consent of the relatives of the patient?

August 31st, 1906. I am, Sirs, yours faithfully,

\section{THE ELECTRICAL RESISTANCE OF THE BLOOD AND URINE AS A TEST OF THE FUNCTIONAL EFFICIENCY OF THE KIDNEY.}

To the Editors of THE LANCET.

SIRS, - My attention has been called to a research by Dr. Dawson F. D. Turner, published in THE LANCET of July $28 \mathrm{th}, 1906$, p. 223 , under this title. It is quite impos. sible to obtain a measure of the concentration of a specimen of blood in salts by measuring the electrical resistance of the blood as Dr. Turner supposes. It has been shown by various observers-first of all by Professor G. N. Stewart $^{2}$ and Roath ${ }^{2}$ independently of each other-that the coloured corpuscles are practically non-conductors owing to their impermeability to the ions of plasma.

The conductivity of blood depends not only on the salts of plasma but on the relative volume of corpuscles and plasma." The reason why Dr. Turner obtains so marked a diminution of resistance in blood in pernicious anæmia is becanse the number of corpuscles is so greatly reduced. It is only by measuring the conductivity of the serum that any notion of its richness in salts can be obtained. I have published results of conductivity measurements ${ }^{*}$ and freezing point observations on blood and serum in numerous diseases. In pernicious anæmia (three cases) I found no warrant for concluding that the proportion of salt is increased.

I am, Sirs, yours faithfully,

Thos Matheson Wilson, B.A. Toronto, M.S. Chicago. Physiology Department, University of Chicago, August 18th, 1906.

\section{WHAT IS A SPECIALIST?}

\section{To the Editors of THE LANCET.}

Sins, - As a contribution $t$ ) the correspondence under the above heading I venture to describe my own case. Four years ago (this coming December) I had to decide whether to resume medical practice as a specialist or as a general practitioner. During the preceding three years 1 had held a hospital appointment near London which offered me facilities to qualify myself specially in eye, ear, and throat work. The cult of pure specialism seemed to present undue financial risks. I therefore purchased a practice in a town with a population of 120,000 without a resident specialist, and having a children's hospital staffed by general practitioners without a single specialist appointment. I entertained hopes of being able to combine general with special practice. I was prepared to face difficulties, for my five years' experience of general practice had been of educational value in certain directions. On taking up my residence in the town $I$ called upon an unusually large number of my medical brethren and after candidly explain. ing $\mathrm{my}$ position sought their support in my special refraction work, \&e. In this connexion, however, I soon discovered that all my cunfrères were bonded by ties of medical fellowship and that they had no "side chains" for a colleague however specialised his claim for professional coöperation. For the first nine months I was content to assist four afternoons a week in the special departments or hospitals of an adjacent city whose medical might overshadowed the town in which I practised. Then I became impatient of playing the part of hospital drudge pour passer le temps. The Micawber-like spirit of waiting served me not. The desire possessed me to secure

I Stewart: Centralblatt fuir Physiologie, 1897, p. 332. 2 Roath : Iljid., 1897, p. 271.

3 Stewart: Journal of Physiology, vol. xxiv., 1879, p. 356. 4 Wilson: American Journal of Physiology, March, 1905, and August, 1906 . 
an appointment as an additional medical officer in my special department at our children's hospital. But my advances in this direction were met with chilling disapproval by the members of the hospital staff. I was speedily made to realise the strength of that barrier wall which is created by provincial hospital men as an exclusionary measure against other medical practitioners residing in the same town. Preventive and hygienic work amongst the children in the schools next offered attractions to me as seeming to afford scope for the energising of my somewhat restless spirit. I was abetted in this by the fact that the medical officer to the education committee was not particularly interested in eye, ear, and throat work. I therefore suggested collaboration with him in this special department, and even framed an elaborate scheme of special medical school inspection which, I believe, was not devoid of some redeeming features. once again did vigorous opposition confront me. I was informed by one and caucus that I, a general practitioner, had ethically no right to assume possession of any special knowledge and experience superior to that of any other general practitioner. This trades union spirit animated the forces fighting against me and-triumphed. My next step was to organise a dispensary for children and diseases of the eye, ear, and throat, of a special, semi-gratuitous, selfsupporting character. On discussing my little scheme with a London ophthalmic surgeon recently $I$ was informed that its analogue can be seen in different continental cliniques, notably that of Dr. Darier of Paris, who was unprovided with a hospital appointment and devised his clinique to meet this want. My scheme went further. It was an honest attempt to solve certain medico-social problems. My medical brethren are attacking my dispensary work by deploying against it a system of covert slander which is more effective than open attack, for I am powerless to combat it. A little later I opened special consulting rooms in our professional square and on a brass plate advertised the fact that I attended at certain hours on certain days for special consultations on diseases of the eye, ear, and throat. This year in Ostend I saw to my joy similarly announced by a medical man consultations for malades des enfants. With great interest I read in the letter of " $\mathrm{S}$. H." of the common custom in Germany and Austria of such door-plate indications. I also notified my patients of my new departure in professional work by means of a printed card and a notice on my bill-heads. For I had to work to live !

These advertising methods have been deemed to be so atrocious that not one medical man has introduced a special case to me at the "Square," or has asked me to meet him in special consultation. My colleagues do not even trouble to reply to my letters respecting their patients who persist in consulting me. Whilst remaining personally friendly with one and all, professionally I am subjected to a boycott which daily menaces me in my practice. I thought to soften the hearts of my opponents by writing a little book which you, Sirs, kindly noticed in a recent number. I find, however, that the local medical men will not buy a copy even at 1 s. net.

In conclusion, I contend that I have a legitimate right thus to push my "specialität," although a "practischer arzt," and that it is degrading to the profession for medical men to encourage, as they do, advertising opticians and hospital abuse, while ostracising members of their own profession. I write my pioneer experiences-pour encourager les autres. I am, Sirs, yours faithfully,

August 27th, 1906. M.D., B.S. LOND., D.P.H. CANiB, \&c.

\section{To the Editors of THE LANCET.}

SIRs,-I am but a comparatively young member of the profession and, no doubt, ignorant of much which may ere long cause me to modify the opinions of which I am at present possessed. I am, however, for the moment bound to aver that your correspondents appear to me to approach this subject from a point of view which is ethically incorrect. I have been connected for the past few years with a special hospital and have devoted a considerable amount of time to the class of disease which is there treated and, supposing that I have brought to bear upon that subject a fair amount of intelligence, may perhaps lay claim to some special knowledge of it. So far, however, as my own feelings are concerned I would not dare to call myself a specialist. I look forward to the time when the public shall regard me as a specialist and when my professional brethren shall know me as one, but to assume the appellation seems to me beyond $\mathrm{my}$ just right. The impression I have derived from my masters in medicine is that no one of them would like to call himself a specialist, though each one would like to be in possession of special knowledge of some particular branch of our science and art. It is at any rate a view with which I am content.

But the strongest argument which can be advanced against the assumption of the term specialist may be advanced from the side of the public. A man in want of a doctor seeing a brass plate with a name and a description of "physician and surgeon," or some equivalent, upon it, knows that within is one whom he may expect to have a reasonable amount of medical knowledge, at least as reasonable as medical authoritative bodies can make it. What is a member of the public to know when he sees the appellation of specialist upon a plate? It may be that the ruan within really has some special knowledge, or it may only be that he thinks he has, or it may be that he desires to give the public the idea that he has it, though in fact he has it not. In any event the man is applying to himself an adjective which no authoritative body vouches for.

August 29th, 1906

I am, Sirs, yours faithfully,

\section{To the Editors of THE LANCET.}

Sins, - It seems to me that the days are past when a man might make up his mind at the outset, or soon after, which branch of our profession he is going to adopt. Certainly this is true with respect to surgery. Let it be granted that a man at the beginning of his career says, "I wish to be a surgeon. I shall so far as possible arrange my work with that end in view. I am not a grasping man and I do not want a plum. I merely wish ultimately to practise surgery as distinct from medicine and I hope I shall be granted facilities for starting in that direction. I am willing to devote so much time to it and to lay out so much capital. Both are above the average amounts." I maintain that, however well such a man may carry out his intentions, however well he may ground himself, and however conscientious and perhaps clever he may be, he is in infinitely greater degree the victim of chance. For instance, it is in the first place, judging from the numbers published, at least two to one against his passing the primary Fellowship examination of the Royal College of Surgeons of England, an examination in two subjects each of which is far too vast for anyone to know the whole of it at once and in which there is no defined schedule. In each only about one tenth of the knowledge is of practical value, the rest is, as a matter of fact, soon forgotten to make room for useful matter. Any particular point in either can be, and is, at once easily revised for purposes of research or for operative procedure. It is said that one can make a certainty of passing this examination and that the best men get through. The first of these statements is quite inaccurate. At any one attempt the element of chance is utterly demoralising. The second statement is in the main true, though numbers pass who never deserve to and numbers fail who would make far better surgeons than many who pass. Many who pass become surgeons simply by reason of having passed, and, indeed, have never from the outset laid down for themselves any plans at all.

In the second place it is at least a two-to-one chance against our man in the final examination. So that only one-ninth of those who enter for the Fellowship of the Royal College of Surgeons of Fingland obtain it. The result time and again is a great loss to the medical profession and to the country, because the requisite qualities of a surgeon cannot be determined finally and wholly by any sort or kind of examination. They might be found out by the apprenticeship system and if the results of original research work were taken into account. At present the quick-witted man with a good temporary memory, who can write quickly, though without a grasp of principles, may happen at the time to be thinking in the same way as the examiner, may pass, while a systematic, plodding man will fail. I maintain that among this eight-ninths of those who desire to become Fellows of the Royal College of Surgeons of England are many who have failed not because they showed themselves incompetent to make good surgeons but because the tests are not properly devised. Failing in examinations there is no alternative proceeding and they are driven to take 
up some branch of the profession which is uncongenial and so to " make a mess" of their liver.

Having, however, passed the examination for the Fellow. ship, and having so become qualified to follow his profession as a pure surgeon by reason of the appointments thrown open to him, the "fortunate" young man has to spend several years in which he might be improving the science and art he has afopted, and his own mind in particular, in grinding out the elements of anatomy to men who will never want onetwentieth part of what is taught them, or in wriling a book before he has had the necessary experience of the subject. When he is past his prime he will perhaps get the chance of practising surgery. At a later stage, just when a record of his experience would be of infinite value to the profession, he is far too sick of it all to set it forth, and little wonder moreover, he has no incentive in the form of future gain. I maintain that this state of things is not conducive to the advancement of the science and art of either surgery or medicine and it follows that the ranks of the specialist, who, either by natural selection or again by chance, are at present taken from a small class, are not filled so well as they could be were the process of selection different. This is undoubtedly to the great loss of the nation.

I am, Sirs, yours faithfully.

August 26th, 1906.

Unlucky Plodder.

\section{PORTUGUESE QUARANTINE REGULA- TIONS.}

(From our Special Sanitary Commissioner.)

\section{Part I.}

The New Law on Maritime Sanitary Precattions.ThE NeW MaRitime Disinfecting Station at OPORTO.

IN respect to maritime sanitation Portugal has a policy of its own. It is governed by a law dated Dec. 24th, 1901, which may be considered an improvement on the international convention adopted at Venice in 1897, though in several respects it is inferior to the international convention subsequently approved at Paris in 1903. In any case, the main practical fact is that communications with Portugal by sea are now less liable to be impeded by sani. tary or quarantine regulations. Undoubtedly Portugal had good reason to be on its guard. It is a poor country and large sections of its population overcrowd very old and insanitary dwellings where they may lack sufficient or suitable food. But apart from these general predisposing conditions, there is a specific reason why the country should have frequently suffered from the importation of epidemic disease. A very large proportion of the maritime trade is with the Brazils and South America where yellow fever abounds among other pestilences, and Portugal has good reason to be careful especially in regard to yellow fever. The bilge water in the old wooden ships facilitated the importation of the larvæ of the stegomyia, and the conditions of the modern copper-bottomed ships are not so favourable to the development of mosquitoes, but, nevertheless, the precautions now taken are less irksome than formerly while losing nothing in thoroughness.

A few years ago when a ship arrived at Leixoes, which is the port for Oporto, it had to proceed to Lisbon if refused free pratique. This is a journey for a steamship of from 12 to 15 hours and involves a great loss of time, coal, and general working expenses. Lisbon was the only port in Portugal possessing a suitable disinfecting station for cases of yellow fever, plague, or cholera. When the cholera prevailed at Hamburg and at Havre ships could not land their passengers or goods at Oporto, for it took less than seven days to come from the infected German and French ports. So great was the trouble and the loss that the Oporto Commercial Association determined to erect a disinfecting station at its own expense and thus save the loss incurred in sending ships and passengers to Lisbon. The new law of 1901 rendered the expediency of such a measure more obvious. According to this law a Portuguese port can only be declared contaminated by the Minister of the Interior through the Director of the Department of Public Health and after the opinion of the General Inspection Services and of the Superior Council of $\mathrm{H}$ g giene has been obtained Even then the presence of cases of plague, cholera, or yellow fever can only be declared when their origin is such as to occasion peril from a sanitary point of view. Undoubtedly a considerable time must elapse between the notification of the first case and the accomplishmen of the above stipulations. In the interval considerable mischief might be accomplished; nevertheless the law formally states that the Governmert alone has the right to proclaim the presence of epidemic disease in a port, and that the port sanitary authority shall not issue a patente brute till after such Government declaration has been officially made. It is known that there are three sorts of patentes. The patente nette is given when the sanitary and health conditions are all that is desirable. The patente brute makes no specification, and patente suspecte does not affirm that the state of health on board was good at the moment of departure. Thus it is evident that the Portuguese Government is very anxious that no unnecessary and premature alarm should be raised; yet it is equally evident that if there be any virtue at all in these sort of precautions this must depend on their being enforced in time.

In regard to the precautions which the new law stipulates must be taken against ships arriving in Portugal, these differ according to the supposed degree of danger, and many clauses in the Act are necessary to deal fully with these varying conditions. Thus there are ships coming from a healthy port with all well on board, but which have had some suspicious communication while in the open sea, or which have an unfavourable anterior record, or have no surgeon on board, \&c. Then there are ships that have stopped for a short time in an unhealthr port. But, and so as not to enter into minute details, the main principle is that the ship must have been at sea seven days without there being any infectious cese of sickness on board. If a ship arrives with all well on board but with a patente brute as coming from a place known to be contaminated, and has been more than seven days at sea, libre pratique is granted to all the passengers after they have undergone a rigorous examination. Their dirty linen, however, is disinfected. The ship and its cargo will be isolated and disinfected and the crew will be disinfected and subject to further medical examinations during seven days. If a ship under the same conditions has been less than seven days at sea the passengers are allowed to land, but they must undergo a rigorous personal disinfection and are only allowed to proceed to places where they can and will be watched medically till the seven days are completed, Should there, however, have been cases of illness on board, and even if these cases terminated by death or recovery more than seven days before the arrival of the ship, the passengers may be detained in quarantine but not for more than 48 hours, and then, when set free, they are to be watched when they reach their destination for seven days more. But this comparative leniency only applies to ships that are in a good sanitary condition and carry a surgeon and a disinfecting stove on board. If these conditions do not obtain then the ship is treated as if there had been cases of illness during the seven days previous to arrival. In that case the passengers are disembarked and isolated in a lazaret where they are kept in rigorous quarantine for seven days. Their luggage and persons are, of course, disinfected, as are also the ship and its cargo. The crew is treated in the same manner. When the danger is that of plague and if the ship has been to a plague-stricken port within the previous three months, or has on board goods coming from a plague-infected locality, all the rats on board must be destroyed and some of them sent to the bacteriological laboratory for examination. If the analyses show the presence of plague among the rats then the entire ship and its cargo must be rigorously disinfected. The same measures must be adopted if the rats die spontaneously on board in such a manner as to make it appear that they are suffering from plague.

Such being some of the more important regulations it will easily be understood that large maritime stations desire to have within easy reach all that is necessary to carry out the law. As, however, the Government is slow to provide the means of applying its own law, the merchants of Oporto spent out of their own pockets some $£ 33,000$ to build a disinfecting station at Leixoes and thus avoid having to send ships to Lisbon. Dr. Oliveira is at the head of this institution, and when I was passing recently through Oporto, he very courteously invited me to visit it. As only small ships 